\title{
Inorganic component of saliva during fasting and after fast break
}

\author{
Yusrini Selviani, Nurul W. Mas'ud, Arsmin NI. Fitri, Atikah B. Ferry, Rini F. Lestari, \\ Rasmidar Samad*
}

\section{Abstract}

Objective: The purpose of this study is to determine the inorganic component of saliva during fasting and after fast break. The study is an observational analytic (longitudinal/follow-up study) conducted in Dental Hospital, Hasanuddin University in July 2015.

Material and Methods: The sampling method is purposive sampling with the entire population of Dental Public Health section students, who are 35 people with 16 research subjects who fulfill the criteria of the study. Samples were tested in the laboratory using atomic absorption spectrophotometer in parts per million units. The data is analyzed by paired t-test with SPSS version 17.0.
Results: Shows that concentration of inorganic components (calcium, phosphate and potassium) in the saliva decreased significantly after fast break $(p<0.05)$. Sodium decreased insignificantly after fast break $(p=0.190)$ and magnesium increased insignificantly after break fasting ( $p=0.615)$.

Conclusion: The concentration of 4 calcium, phosphate, potassium except sodium decreased significantly after fast break, whereas the concentrations of magnesium were not significantly increased after fast break.
Department of Dental Public Health, Faculty of Dentistry, Hasanuddin University, Makassar, Indonesia

*Correspondence to: Rasmidar Samad

hscrp.samad@gmail.com

Received: 09 March 2016

Revised: 15 August 2016

Accepted: 17 August 2016

Available Online: 31 August 2016
Keywords: Saliva, Inorganic, Fasting

Cite this Article: Selviani, Y., Mas'ud, N.W., Fitri, A.N.I. 2016. Inorganic component of saliva during fasting and after fast break. Journal of Dentomaxillofacial Science 1(2): 118-121. D0l:10.15562/jdmfs.v1i2.10

\section{Introduction}

Saliva is an exocrine liquid secreted into oral cavity through three pairs of saliva glands (parotic gland, submandibular gland and sublingual gland), minor saliva gland and gingival fluid. Saliva has many functions in the oral cavity such as cleanser of food debris, helping digestion and mastication of food, setting water balance, maintaining the integrity of the tooth, antibacterial activity, antifungal and antiviral, neutralizing the atmosphere of oral cavity tissue damaged by strong acid and alkaline. ${ }^{1}$

Saliva consists of $94-99.5 \%$ water, organic and inorganic component. The inorganic include $\mathrm{Na}^{+}$, $\mathrm{K}^{+}, \mathrm{Ca}^{2+}, \mathrm{Mg}^{2+}, \mathrm{Cl}, \mathrm{SO}_{4}, \mathrm{H}_{2} \mathrm{PO}_{4}, \mathrm{HPO}_{4}, \mathrm{SCN}, \mathrm{F}, \mathrm{H}_{2} \mathrm{PO}_{4}$ and $\mathrm{HPO}_{4}$, whereas the main organic components is protein, enzyme, immunoglobulin, lipid, glucose, amino acid, urea, ammonia, vitamin, mucus glycoprotein, albumin, some oligopeptide and polypeptide which are important for oral cavity. ${ }^{2}$

Calcium, sodium, potassium, magnesium and phosphate are found in ionic forms. These inorganic components play an important role in oral cavity. In saliva, calcium assists in remineralization process of dentin and teeths' enamel, sodium contributes in sending impulse to the nerve process, supporting muscle cell contraction and maintaining body fluid, magnesium plays important role in neuromuscular activity, central nerve system, heart beat rhythm, fibrinolysis promoter as a vasodilator agent, and immune system builder. Phosphate in the enamel is required as a constituent of the hydroxyapatite molecules, whereas in plaque and saliva it is required for remineralization process and buffer saliva and Potassium are the major cations found in the intracellular fluid (joint bicarbonate) which serves as the primary buffer. Ramadan is the ninth month in the islamic lunar calendar (hijra), which has great significance for all muslims in the world. In this month, every muslim must perform fasting for one month. This activity changes their meal and drink times, which in turn will affect the production of saliva due to the lack of activity of mastication in the cavity. In additional the saliva component also will be different. If the component of saliva changes, it can cause damage in cavity. Therefore, the purpose of this study is to examine the inorganic content of saliva during and after fasting. Besides that, the study will also analyze the total concentration of calcium, sodium, potassium, magnesium and phosphate during fasting and after breakfast. ${ }^{3-9}$ 


\section{Material and Methods}

The study is observational analytic with longitudinal design (follow up study). The study was conducted at Dental Hospital, Faculty of Dentistry, Hasanuddin University, Makassar, Indonesia in July 2015. The population of this study was 35 students from Department of Dental Public Health Faculty of Dentistry Hasanuddin University and total saliva samples are 16 clinical students who fit with the criteria of research subjects.

Inclusion criteria for this study are the Muslim clinic students who are performing fasting. Exclusion criteria in this study is the subject who is undergoing orthodontic treatment, taking antibiotics, using a prosthesis, has a systemic disease and the habit of smoking. The inorganic content is measured by Atomic Absorption Spectrophotometer (AAS) in Parts Per Million ( $\mathrm{ppm}$ ) units derived from saliva collected in the tube during fasting and after breakfast.

Samples were collected at 11:00 pm during fasting in the morning. To obtain saliva, subjects in a resting state bowed his head and samples were collected into sterile plastic bottles up to half or about $5 \mathrm{ml}$. Then, the bottles were attached with an identification label and stored in refrigerator to prevent chemical alteration in samples. The samples were sent to BPTP Maros Laboratory to measure their inorganic component by AAS. The samples were collected at 20:30 pm, which is 90 minutes after fast break. To obtain saliva, subjects in a resting state bowed their head and samples were collected into sterile plastic bottles up to half or about $5 \mathrm{ml}$. Then, the bottles were attached with an identification label and stored in refrigerator to prevent chemical alteration in samples. The samples were sent to BPTP Maros Laboratory to measure their inorganic component by AAS.

Data were processed using SPSS version 17.0 and analyzed using paired t-test with significant $\mathrm{p}$ value of $<0.05$. The data was presented in table.

Table 1 Inorganic component of saliva during fasting and after fast break

\begin{tabular}{|c|c|c|c|c|c|}
\hline \multirow[t]{2}{*}{$\begin{array}{l}\text { Mineral } \\
\text { (ppm) }\end{array}$} & \multirow[b]{2}{*}{$\mathbf{N}$} & \multirow{2}{*}{$\begin{array}{l}\text { Normal } \\
\text { state }\end{array}$} & During fasting & \multirow{2}{*}{$\begin{array}{c}\begin{array}{c}\text { After fast } \\
\text { break }\end{array} \\
\text { Mean } \pm \text { SD }\end{array}$} & \multirow[b]{2}{*}{ p-value } \\
\hline & & & Mean \pm SD & & \\
\hline Calcium & 16 & 100.2 & $106.75 \pm 24.47$ & $78.75 \pm 22.00$ & $0.002^{*}$ \\
\hline Phosphate & 16 & 190 & $68.50 \pm 18.35$ & $23.12 \pm 6.62$ & $0.000^{*}$ \\
\hline Calium & 16 & $360-480$ & $942.31 \pm 284.32$ & $467.44 \pm 138.1$ & $0.000^{*}$ \\
\hline Magnesium & 16 & $4.86-14.58$ & $2.18 \pm 1.23$ & $2.35 \pm 1.34$ & $0.615^{\star}$ \\
\hline Sodium & 16 & $46-1150$ & $192.62 \pm 39.34$ & $160.25 \pm 64.05$ & $0.190^{*}$ \\
\hline
\end{tabular}

Significance $\mathrm{p}<0.05$

\section{Results}

From the table 1 . The data shows that the concentration of potassium in the saliva declined after fast break. In the normal state, total potassium in saliva is $360-480 \mathrm{ppm}$. The data shows a decrease in potassium concentration after fast break below the normal limit of $467.44 \mathrm{ppm}$, whereas during fasting the potassium concentration is above the normal limit of $942.31 \mathrm{ppm}$. This is because during fasting salivary flow decreased because of mastication of food or it is unstimulated. In this study, salivary flow during fasting decreased while the potassium ion concentration is higher, this means that the salivary flow correlated negatively with potassium.

Table 1 also shows the concentration of calcium, phosphate and potassium in saliva decreased significantly after fast break ( $\mathrm{p}=0.002$ for calcium, for phosphate $\mathrm{p}=0.000$ and $\mathrm{p}=0.000$ for potassium). The mean of total calcium concentration $(\mathrm{ppm})$ during fasting was at 106.75 with a standard deviation of 24.47 and the mean of total calcium concentration (ppm) after fast break was at 78.75 with a standard deviation of 22.00 . The mean of concentration of phosphate at 68.50 with a standard deviation of 18.35 , while after fast break was at

23.12 with a standard deviation of 6.62 . The mean concentration of potassium during fasting was at 942.31 with a standard deviation of 284.32 and after fast break was at 467.44 with a standard deviation of 138.14 .

The mean of total magnesium concentration (ppm) during fasting was at 2.18 with a standard deviation of 1.231 and after fast break was at 2.35 with a standard deviation of 1.34 . This shows magnesium concentration has nonsignificantly increased after fast break ( $\mathrm{p}=0.615)$.

Table 1 shows the mean of sodium concentration (ppm) during fasting was at 192.62 with a standard deviation of 139.34 and after fast break was at 160.25 with a standard deviation of 64.05 . This represents an insignificant reduction in the concentration of sodium ions in saliva after fast break $(\mathrm{p}=0.190)$.

\section{Discussion}

In this research, samples were collected at 11:00 pm during fasting due to the process of circadian rhythm that worked at that time. In line with Karami-Nougurani et al. ${ }^{10}$ stated that in order to avoid the possibility of confounding effects from circadian rhythms in salivary flow, the research have to carry out at 9:00-11:00 am. The circadian rhythm is a rhythm of the body that is "up" and "down" regularly in the span of about 24 hours. This 
concentration of the various components of saliva is characterized by their impact on the variation of salivary flow.

The second sampling was carried out 90 minutes after fast break, because the circumstance of the $\mathrm{pH}$ in the oral cavity has returned to a normal state. This is supported by research from Higham ${ }^{12}$ who stated that, based on the Stephan curve graph showing that a $\mathrm{pH}$ of 5.5 or less indicates the occurrence of demineralization, and $\mathrm{pH}$ levels will stay down or in a "critical level" for approximately 20 minutes, $\mathrm{pH}$ was completely back to normal or resting state about 45-60 minutes after mealtime.

In this study, the concentration of calcium decreased significantly after fast break. Based on the normal concentration, total calcium in saliva is equal to $1-2.5 \mathrm{mMol} / \mathrm{L}$ or $100.2 \mathrm{ppm}^{13}$ and after fast break, the calcium concentration is equal to $78.75 \mathrm{ppm}$, which indicates that there is a decrease in calcium concentrations below the normal limit. This is due to the stimulation of mastication, causing an increase in salivary flow. Indriana ${ }^{14}$ argued that increase in salivary flow could affect minerals in saliva. The increase in salivary flow rate causes a decrease in salivary calcium concentration. The calcium in saliva plays a role in maintaining the integrity of the teeth by regulating remineralization, if the salivary calcium is low, it will be one of the factors of demineralization.

Demineralization is the release of inorganic mineral hydroxyapatite structure at a $\mathrm{pH}$ below 5.5 (the critical pH). If the concentration of calcium in saliva is lower than enamel, the enamel will dissolve the minerals. Therefore, the amount of minerals in the saliva and plaque is same as in enamel. The presence of calcium ion release enamel, which continues to loss a little amount of enamel element and if it had been up to dentin then the patient will feel pain. ${ }^{6}$ Hasanah et al. ${ }^{15}$ stated if the calcium in teeth is irreplaceable, then the excess calcium will diffuse in to the surrounding environment. Demineralization will stop in case the $\mathrm{pH}$ and calcium in saliva increases resulting in remineralization process.

The phosphate concentration decreased significantly after fast break. This is because during fasting, humans have not eaten or taken drink for 12 hours that led to an absence of stimulation of saliva, so the salivary flow decreases and affects salivary calcium and phosphate concentrations. When the $\mathrm{pH}$ of saliva during fasting is normal or non-acidic due to lack of food intake, thereby reducing the amount of bacteria in saliva that can speed up teeth's enamel demineralization. ${ }^{14}$ This is according to research conducted by Hasanah et al..$^{15}$ who said that when the $\mathrm{pH}$ in the oral cavity is acidic, it will produce a decrease in the concentration of hydroxyl and phosphate leading to demineralization.

The concentration of potassium in the saliva declined after fast break. Based on the normal state, total of potassium in the saliva is $360-480 \mathrm{ppm}^{7}$ This shows a decrease in potassium concentration after fast break in the normal limit of $467.44 \mathrm{ppm}$, while at fasting potassium concentration is above the normal limit of $942.31 \mathrm{ppm}$. This is because at the time of fasting salivary flow decreases die to mastication of food or is unstimulated. In this study, salivary flow during fasting decreased, while potassium concentration is higher, which mean that salivary flow correlated negatively with potassium. This is according to research conducted by Sevon ${ }^{16}$ who stated that salivary flow negatively correlated with magnesium, potassium and phosphate and positively correlated with protein and sodium. There is a positive correlation between salivary flow rates, calcium, sodium and an inverse correlation in salivary flow with potassium.

Magnesium concentration has increased to a nonsignificant level after fast break. Normal concentration of magnesium in the saliva is equal to $4.86-14.58 \mathrm{ppm}^{13}$ whereas in this study, a decrease in magnesium concentration below the normal limit of the results obtained during fasting is $2.18 \mathrm{ppm}$ and $2.35 \mathrm{ppm}$ after fast break. Study by Skomro ${ }^{17}$ shows obtaining magnesium in healthy people is at $0.14 \mathrm{mmol} / \mathrm{L}$ or $3.40 \mathrm{ppm}$. Whereas, other researches on the composition of the saliva does not report the total of magnesium ions due to a low concentration.

In this study, decreased magnesium ion concentrations during fasting are due to reduced salivary flow. This is in line with Johanson et al. ${ }^{18}$ who reported that the fast with a short time can reduce salivary flow and it is influenced by physiological and psychological factors when fasting. However, there are different results with Sevon ${ }^{16}$ the research found no changes in the concentration of magnesium on salivary flow. This may be due to a body state that varies between individuals that affect the composition of saliva. Several other studies confirm that the composition of the saliva flow rates varied and differ in each individual every day. It is also caused by factors of age and gender, which differs for each individu. ${ }^{17}$ The concentration of magnesium in the body is mainly influenced by the concentration of magnesium in plasma. Magnesium excretion is influenced by the concentration of calcium and phosphate. The movement of magnesium generally follow the movement of phosphate that is, if the phosphate decreased, then the magnesium also decreases and it is inversely proportional to calcium. ${ }^{19}$ 
The sodium concentration of saliva decreases when fasting and after fast break is still within normal limits. It is based on the normal concentration of sodium in saliva of $2-50 \mathrm{mMol} / \mathrm{l}$ or 46-1150 ppm. ${ }^{13}$ According to research conducted by Johansson et al. ${ }^{18}$ and Sariri et al. ${ }^{20}$ that during fasting salivary flow decreased. Also in the study by Develioglu et $\mathrm{al}^{21}$ shows that concentration of sodium depends on the salivary flow, salivary flow rate increase with increased concentration of sodium. In contrast, in this study showed sodium concentrations decreased after fast break. Decrease in sodium concentrations after fast break can be caused due to fewer intakes of nutrition, hydration levels of individuals and circadian cycles.

\section{Conclusion}

The concentration of calcium, phosphate and potassium except sodium decreased significantly after fast break, whereas the concentrations of magnesium were not significantly increased after fast break.

\section{Conflict of Interest}

The authors report no conflict of interest

\section{References}

1. Almaida PV, Gregi A, Azevedo LR. Saliva composition and function. J Contemp Dent Pract 2008;9: 1, 2-5, 7 .

2. Semiyari H, Farhadi S, Taheri RA, et al. Comparison of salivary micro flora of fasting and no fasting persons. Research J Bio Sci 2010: 5.

3. Tamsuri A. Klien gangguan keseimbangan cairan dan elektrolit. Jakarta: EGC; 2004. p. 22-23.

4. Andrusishina IN. Diagnostic values of calcium and magnesium forms determined in human serum and saliva. J Elementol 2010;15: 425-433.

5. Kidd EAM, Bechal SJ. Dasar-dasar penyakit caries dan penanggulangannya. Jakarta: EGC; 1992. p. 66.

6. Prasetyo AE. Keasaman minuman ringan menurunkan kekerasan permukaan gigi. Maj Ked Gigi (Dent J) 2005;38: 60 .
7. Kementerian Kesehatan Republik Indonesia. Jakata: Pedoman Interpretasi Data Klinik; 2011. p. 30.

8. Bragazzi NL. Ramadan and oral pathologies. In Hamdi Chtourou, editor. Effects of eamadan dasting on health and athletic performance 2014 .

9. Satria B, Sutadi H, Mangundjaja S. The differences level of CFU of mutans streptococci in saliva of schoolchildren during fasting and non-fasting. Department of oral biology faculty of dentistry universitas Indonesia 2009.

10. Karami-Nogourani M, Kowsari-Ishafan R, HosseiniBeheshti M. The effect of chewing gum's flavor on salivary flow rate and $\mathrm{pH}$. Dent Res J 2011; 8.

11. Wu KP, Ke JY, Chung CY, et al. Relationship between unstimulated salivary flow rate and composition of healthy children in Taiwan. Chang Gung Med J 2008; 31.

12. 13. Higham S. Caries process and prevention strategies: the environment. Www.dentalcare.com/enUS/dentaleducation/continuingeducation/ce371/ce371.aspx, Accessed by August 31, 2015.

13. Vasudevan DM, Sreekumari S, Kannaan V. Textbook of biochemistry for dental student 2 nd ed. India: Jaypee; 2011. p. 67-69.

14. Indriana T. Perbedaan laju aliran saliva dan $\mathrm{pH}$ karena pengaruh stimulus kimiawi dan mekanis. J Kedokt Meditek 2011;17: 2.

15. Hasanah I, Setyorini D, Sulistyani. Kadar ion fosfat dalam saliva buatan setelah aplikasi ccp-acp. AIHPM 2014.

16. Sevon L. Effect of age on flow-rate, protein and electrolyte composition of Stimulated whole saliva in healthy, non-smoking women. Open Dent J 2008;2: 89-92.

17. Skomro1 P. Limited effect of low frequency magneticfields on the concentrations of calcium, magnesium and fluoride in saliva. Magnesium Res 2009;22: 89-92.

18. Johansson I, Ericson T, Steen L. Studies of the effect of diet on saliva secretion and caries development: the effect of fasting on saliva composition of female subjects. Nutr J 1984, 2010-2020.

19. Lau A, Chan LN. Basic skills in interpreting laboratory data. 5thed. Electrolytes, other mineral and trace elements. American society of health system pharmacist 2013: 131-132.

20. Sariri R, Varaseth A, Erfani A. Alternation in salivary glucose during ramadan fasting. J Health 2010: 769-772.

21. Develioglu ON, Kucur M, Ipek HD, et al. Effets of ramadan fasting on serum immunoglobulin $\mathrm{G}$ and $\mathrm{M}$ and salivary immunoglobulin A concentrations. J Intl Med Res 2013: $463-472$.

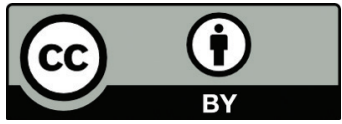

This work is licensed under a Creative Commons Attribution 